\title{
世界の平和と 「平和の文化」
}

ーインド・ジャイプール国際会議 一

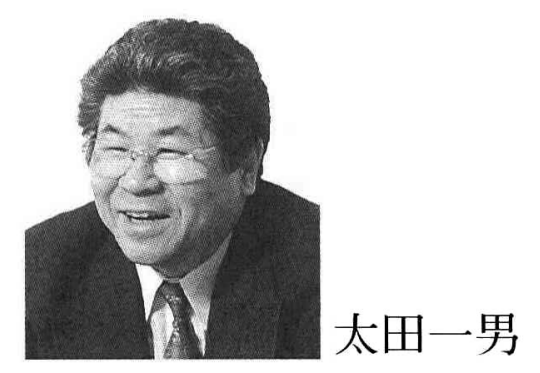

国文

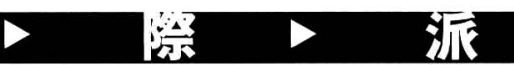

$\checkmark$

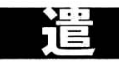

$\triangleright$

为5

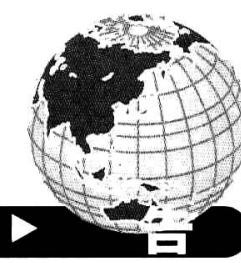

\section{ガンジィ一研究所の イニシアチブで開催}

2001年12月、年の瀬も迫った27日から30日に かけて、インドのジャイプール大学・ガンジィ 一研究所を会場として「平和の文化」国際会議が 開催された。

国連の「平和の文化年」を考慮されての国際会 議が、非暴力平和共存を説き追究してきたイン ドのガンジィー研究所のイニシアチブで準備さ れ、開催された意義は大きいと考え、参加させ ていただいた。

この会議が計画され、世界の平和研究者に参加 の呼び掛けが送られたときには、世界各地から多 くの参加の申し出があったのであるが、「9・11の 事件」は、この会議にも大きな影を落としてしま った。アメリカのみならず、ヨーロッパ各地から
も参加者が激减して、参加者は12力国、106名と いう規模のものとなってしまった。

会議を中心となって準備して下さったジャイ プール大学のナレシュ・ダデイチユ博士は、こ の種の会議の常として、外国からの参加者も含 めて会議の費用負担を期待されていたようであ るが、外国からの参加者の激減は、会の運営に も課題を残したようである。

\section{グローバル化がもたらした 構造的な矛盾に遭遇}

私は、会議の開会に際して、外国からの参加 者の代表として、ガンジィ一の遺影に献花を捧 げる役割と開会の挨拶をする栄に浴し、加えて、 オープニング講演をさせていただいた。

開会に際し、おおむね、以下のようなことを 申し上げ、その責めを果たさせていただいた。 
今、世界は、グローバライゼイションと一般 にいわれる新しい社会関係の一般化と世界化の 深まりの中で、世界的な規模で、「肥満と饑餓」 「浪費と欠乏」「高度な科学技術文明と棄民の群 れ」という構造的な矛盾に遭遇して、その出口 を見い出せないでいる。この矛盾は、近代の主 権国家の関係の枠組みを超えた関係の中で生じ てきていることであり、近代の主権国家の枠組 みでできた考え方やものの見方では、整理でき ないものである。

私の考えでは、今世界に起こっている様々な 出来事は、「高度に発達した科学技術を組織し てほぼすべてのものを工業制商品」として生産 し、世界を一つの市場とし機能させてきている 生産関係と、その上に形成されてきている社会 関係の上に、生じているものと考えている。こ の新しい生産様式のことを「高度科学技術工業 制商品生産様式」といい、この英語表現一Higly Advanced Scientific Techunological Industrial Commodities の頭文字を用いて「HASTIC」と いう。

\section{「HASTIC」の世界化が 醸造する負の現実}

$\lceil$ HASTIC」生産社会関係の世界化と一般化は、 経済のグローバル化をもたらしただけではな く、情報や技術や労働や人の移動や文化などす べてのものの関係を世界化し、その「負の現実」 として、これまで多くの人々を養ってきた在来 の様々な仕事が消えていく消業、失業、半失業、
不安定就業、パートタイム労働、就業不能、超 国家的市場関係次元での多様な形での就業等 人々の不安定な就労関係を拡大し、世界各地で の社会的不安定要因を日常的に醸造する社会構 造を拡大してきていている。

従来、地域社会の秩序を維持することでその 役割を果たしてきた主権国家の多くが、 $\lceil$ HASTIC」生産社会関係の一般化の波に飲み込 まれて、債務国となり、その通貨の国際的価値 のみならず国内での信用力さえも弱くして、 「発展途上諸国」の治安維持能力を弱め、世界の 各地で、様々な「地域紛争」を引き起こす原因と なっている。

他方、「HASTIC」生産社会関係の世界化は、 政治の課題として、「軍事侵略」や「軍事占領」 を機能させる次元をなくしてきていて、「自衛 のための軍隊」や「国防のための軍隊」は不要と なり、軍は自国民を弾圧したり、大量の浪費機 構として機能する「官機構」一「人々の就職先」と なってきているのである。

また、「HASTIC」生産社会関係の世界化は、 人々に「地球球体の有限性」を広く認識させて きており、それは、これまでの「浪費を基調と する商品経済」のあり方や文明の質をも問うと ころとなり、やがて人類は「浪費を慎み、足る を知る文明」を追究するようになる。その時に は、各国の軍隊は「最大の浪費機構」として、解 体の課題となるものと思われる。

これからの「平和の文化」は、巨大な浪費機構 としての各国の軍隊をどのように縮小解体し、 
人々の医療や福祉や教育の充実に向け、人類が

この限られた地球環境のもとで共に生きていく

ことのできる社会関係を築いていくことができ るのかを、様々な角度から検討していくことに あると思われる。

人々の共生を求めて、非暴力を説いたガンジィ 一の哲学は、これからますます人類の大きな導 きの星となる。

私自身の報告は、この観点に立って、日本国
憲法の役割を明らかにすることにあった。

会議では、インド・パキスタン問題など地域 紛争の非軍事化の可能性についてなど、多方面 からの報告が提出されていた。

太田 一男 （おおた かずお 1935年生

酪農学園大学環境システム学部教授、平和問題研究会連 絡委員

専門：憲法学、政治学、国際環境関係論、ユーゴ研究
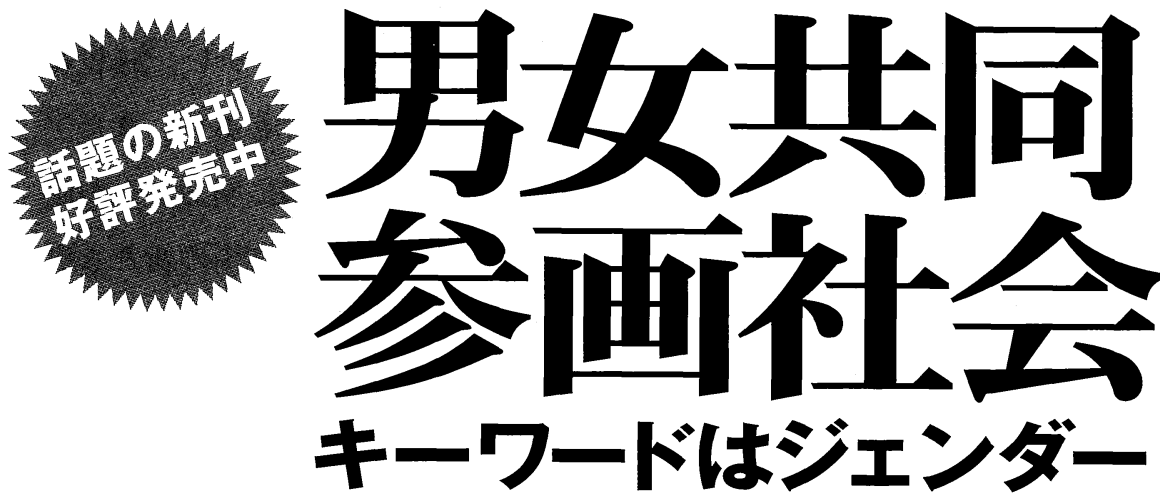

学術会議叢書 3

\section{ジェンダーとは}

男と女、性別と性差とは

A5判、171頁

男女共同参画社会の実現が叫ばれる中、

定価：本体 1,800 円税

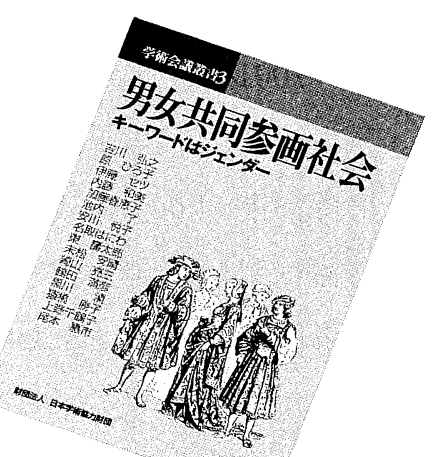
その現状と分析、今後の展望などについて、 日本を代表する女性科学者をはじめ、各分野の專門家が提言

編集協力………日本学術会議事務局

編集・発行 ……財団法人日本学術協力財団

制作・発売…... 株式会社ビュープロ
【お問い合せ・お申し込み先】

財団法人 日本学術協力財団

于 106-0031 東京都港区西麻布3-24-20

電話 : 03 (5410) 0242 FAX : 03(5410) 1822 